\title{
The mass balance model perfectly fits both Hall et al. underfeeding data and Horton et al. overfeeding data
}

\author{
Francisco Arencibia-Albite ${ }^{1}$ Anssi H. Manninen ${ }^{2}$
}

${ }^{1}$ Universidad del Sagrado Corazón, Natural Sciences Department, PO BOX 12383, San Juan PR 00914-0383, Puerto Rico. Email: franciscom.arencibia@sagrado.edu

${ }^{2}$ Dominus Nutrition Oy, Ylipääntie 438, 92220 Raahe, Finland. Email: anssi@dominusnutrition.fi

Corresponding author: Anssi H. Manninen 
medRxiv preprint doi: https://doi.org/10.1101/2021.02.22.21252026; this version posted March 3, 2021. The copyright holder for this preprint (which was not certified by peer review) is the author/funder, who has granted medRxiv a license to display the preprint in perpetuity.

\section{Abstract}

\section{Background \& Aims}

Recently, the validity of mass balance model (MBM) was questioned based on two feeding studies. Thus, we simulated both of these feeding trials.

\section{Methods}

MBM describes the temporal evolution of body weight and body composition under a wide variety of feeding experiments. This computational study simulated, utilizing MBM, the underfeeding trial by Hall et al. (Cell Metab. 2015;22:427-36) and the overfeeding trial by Horton et al. (Am J Clin Nutr. 1995;62:1929).

\section{Results}

Our simulation results indicate that data from both of these feeding trials perfectly match MBM-based predictions, i.e., MBM gives a remarkably accurate description of experimental data.

\section{Conclusions}

It is becoming increasingly clear that our model (MBM) is perfectly able to predict body weight and body composition fluctuations under a wide variety of feeding experiments. 
medRxiv preprint doi: https://doi.org/10.1101/2021.02.22.21252026; this version posted March 3, 2021. The copyright holder for this preprint (which was not certified by peer review) is the author/funder, who has granted medRxiv a license to display the preprint in perpetuity.

It is made available under a CC-BY-NC-ND 4.0 International license .

Key words: obesity, weight loss, energy balance theory, mass balance model, macronutrients

"There is a stupid humility that is not at all rare, and those afflicted with it are altogether unfit to become devotees of knowledge. As soon as a person of this type perceives something striking, he turns on his heel, as it were, and says to himself: "You have made a mistake. What is the matter with your senses? This cannot, may not, be the truth." And then, instead of looking and listening again, more carefully, he runs away from the striking thing, as if he had been intimidated, and tries to remove it from his mind as fast as he can. For his inner canon says: "I do not want to see anything that contradicts the prevalent opinion. Am / called to discover new truths? There are too many old ones, as it is..."

- Friedrich Nietzsche, The Gay Science (1882)

\section{Introduction}

Currently, weight management is based on the "calories-in, calories-out" rule, formally named the energy balance theory (EBT). It maintains that body weight increases as food calories are greater than expended calories and vice versa. However, our recent papers [1,2] indicate that EBT-based simulations are clearly erroneous. As an alternative, the mass balance model (MBM) was proposed; and our recent simulations $[1,2]$ indicate that MBM-based predictions are remarkably accurate.

Recently, the validity of mass balance model (MBM) was questioned based on two feeding studies, namely the underfeeding trial by Hall et al. [3] and the overfeeding study by Horton et al. [4]. Thus, we decided to simulate, utilizing MBM, both of the above mentioned feeding trials.

\section{Materials \& Methods}

\section{Mass balance model (MBM)}

The MBM describes the temporal evolution of body weight and body composition under a wide variety of feeding experiments by using of the following measurements:

Energy-providing mass (EPM): The daily mass intake given by carbohydrate, fat, protein, soluble fiber and alcohol. 
medRxiv preprint doi: https://doi.org/10.1101/2021.02.22.21252026; this version posted March 3, 2021. The copyright holder for this preprint (which was not certified by peer review) is the author/funder, who has granted medRxiv a license to display the preprint in perpetuity.

It is made available under a CC-BY-NC-ND 4.0 International license .

Non-energy-providing mass (nEPM): The daily mass intake given by insoluble fiber, vitamins, minerals and the net daily water balance (i.e., water ingestion and metabolically produced water minus lost water).

R: The relative daily rate of mass excretion free of total daily $\mathrm{O}_{2}$ uptake.

$\boldsymbol{\beta}$ : The mathematical formula that approximates the relationship between $\mathrm{dFFM} / \mathrm{dFM}$ and $\mathrm{FM}$ is an equilateral hyperbola where $\beta$ is the constant term of the hyperbola, i.e., $F M(d F F M / d F M)=\beta$. This parameter sets the magnitude of the change in fat free mass (FFM) whenever fat mass (FM) changes.

These measurements are used to populate the following MBM formulas:

$$
\begin{gathered}
M=E P M+n E P M \\
\Delta B W(t)=\left(M / R-B W_{0}\right)\left\{1-[1-R]^{t}\right\} \\
\Delta F M(t)=\beta \cdot W\left\{\left(F M_{0} / \beta\right) \exp \left[\Delta B W(t) / \beta+F M_{0} / \beta\right]\right\}-F_{0}
\end{gathered}
$$

where $t$ is the time in days; $M$ is the total daily mass intake; $B W_{0}$ is the initial body weight; $\Delta B W(t)$ and $\triangle \mathrm{FM}(\mathrm{t})$ are the cumulative body weight and fat mass changes, respectively; $\mathrm{FM}_{0}$ is the initial fat mass; and $W$ is the product log function. For further details, consult the original MBM paper [1].

\section{MBM and Hall et al. underfeeding data}

As was already pointed out by Arencibia-Albite in "Discussion" of the original MBM paper [1], this model, in fact, perfectly fits Hall et al. data [3]. In their Table 3 and Figure 3F, it is shown that a period of six days of reduced carbohydrate diet $(\mathrm{RC})$ resulted, on average, in a total weight loss of $-1.85 \mathrm{~kg}$, whereas the reduced fat diet (RF) resulted in $-1.3 \mathrm{~kg}$ ( $R C$ vs. $R F, p=0.022$ ). According to their Table 1, EPM of each diet is as follows:

$$
\begin{aligned}
& R C: \quad E P M=0.365 \mathrm{~kg} \\
& \text { RF: } \quad E P M=0.495 \mathrm{~kg}
\end{aligned}
$$

while the average $\mathrm{BW}_{0}$ and $\mathrm{FM}_{0}$ are $106 \mathrm{~kg}$ and $42 \mathrm{~kg}$, respectively.

Using this data and standard numerical methods, we approximated that the remaining MBM parameters were:

\begin{tabular}{ccc}
\hline Parameters & RC & RF \\
\hline nEPM & $1.4846 \mathrm{~kg}$ & $1.6055 \mathrm{~kg}$ \\
R & 0.0205109 & 0.0219753 \\
B & $104.2324 \mathrm{~kg}$ & $50.5016 \mathrm{~kg}$ \\
\hline
\end{tabular}

Therefore, the MBM formulas for each diet are as follows: 
$\mathrm{RC}:$

$$
\begin{gathered}
M=E P M+n E P M=1.8496 \mathrm{~kg} \\
\Delta \mathrm{BW}(\mathrm{t})=(1.8496 / 0.0205109-106)\left\{1-[1-0.0205109]^{\mathrm{t}}\right\} \\
\Delta \mathrm{FM}(\mathrm{t})=104.2324 \cdot \mathrm{W}\{(42 / 104.2324) \exp [\Delta \mathrm{BW}(\mathrm{t}) / 104.2324+42 / 104.2324]\}-42
\end{gathered}
$$

RF:

$$
\begin{gathered}
M=E P M+n E P M=2.1005 \mathrm{~kg} \\
\Delta \mathrm{BW}(\mathrm{t})=(2.1005 / 0.0219753-106)\left\{1-[1-0.0219753]^{\mathrm{t}}\right\} \\
\Delta \mathrm{FM}(\mathrm{t})=50.5016 \cdot \mathrm{W}\{(42 / 50.5016) \exp [\Delta \mathrm{BW}(\mathrm{t}) / 50.5016+42 / 50.5016]\}-42
\end{gathered}
$$

These formulas are plotted in Figure 1. For further details, see the figure legend.

\section{A1}

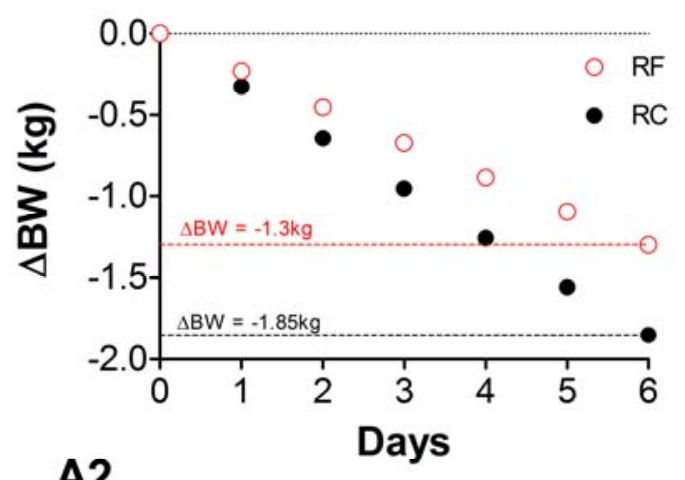

A2

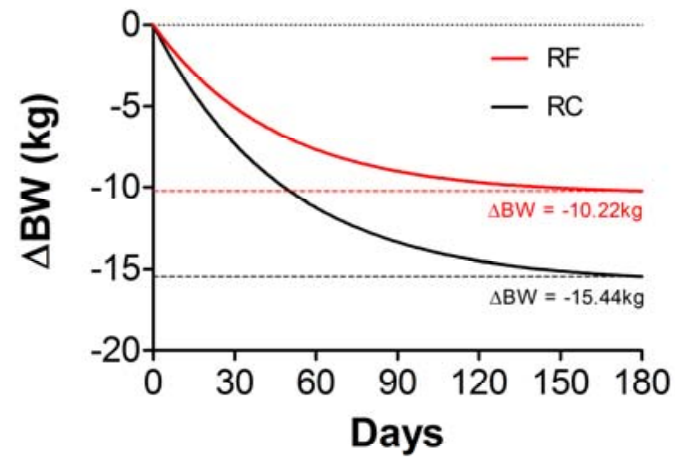

\section{B1}

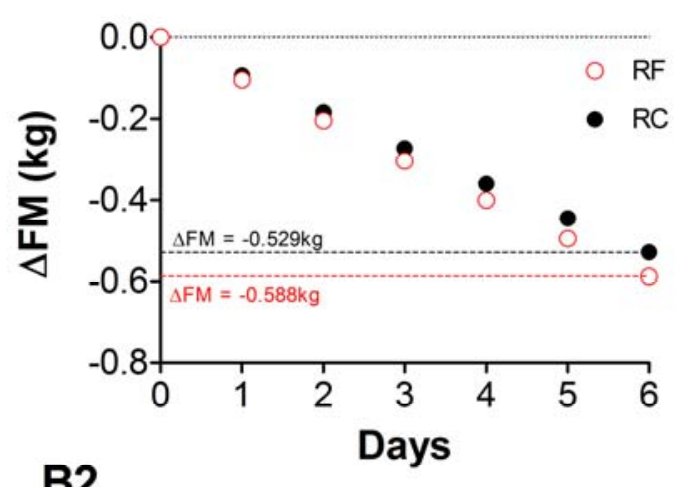

B2

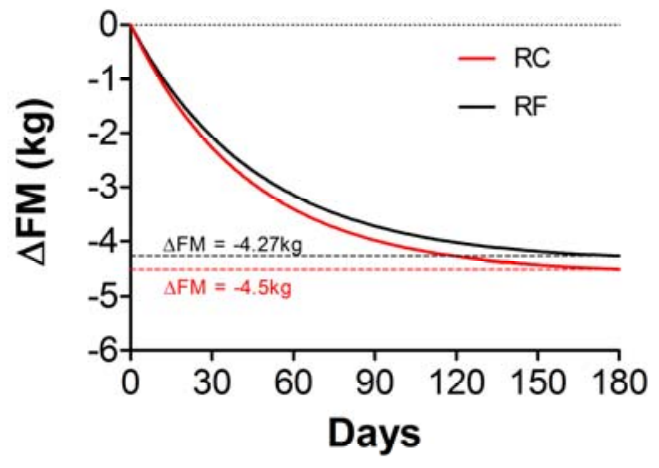


medRxiv preprint doi: https://doi.org/10.1101/2021.02.22.21252026; this version posted March 3, 2021. The copyright holder for this preprint (which was not certified by peer review) is the author/funder, who has granted medRxiv a license to display the preprint in perpetuity.

It is made available under a CC-BY-NC-ND 4.0 International license .

[FIGURE LEGEND STARTS] Figure 1. MBM simulation of Hall et al. underfeeding data. A1. MBM weight loss trajectories perfectly match those reported by Hall et al. [3] over the trial duration (6 days). A2. The graph shows the same weight loss trajectories as in panel A1 but extended for 180 days. The MBM predicts a greater weight loss in the RC diet in contrast to the RF diet. B1. Fat loss trajectories that underlay weight loss in A1 perfectly match those reported by Hall et al. [3] over the trial duration (6 days). B2. The graph shows the same fat loss trajectories as in panel B1 but extended for 180 days. The MBM predicts very similar levels of fat loss between diets. [FIGURE LEGEND ENDS]

\section{MBM and Horton et al. overfeeding data}

According to Table 1 in Horton et al. [4], the average initial characteristics of the lean and obese subjects were as follows:

\begin{tabular}{ccc}
\hline & Lean & Obese \\
\hline BW $_{\mathbf{0}}$ & $68.4 \mathrm{~kg}$ & $103.9 \mathrm{~kg}$ \\
$\mathbf{F M}_{\mathbf{0}}$ & $14.7 \mathrm{~kg}$ & $37 \mathrm{~kg}$ \\
\hline
\end{tabular}

After an isocaloric overfeeding period of 14 days, the latter characteristics change (Table 2 in Horton et al. [4]):

\section{Lean Obese}

High Carb. (HC) High Fat (HF) High Carb. (HC) High Fat (HF)

\begin{tabular}{lllll}
\hline$\Delta \mathrm{BW}$ & $2.47 \mathrm{~kg}$ & $2.31 \mathrm{~kg}$ & $3.47 \mathrm{~kg}$ & $2.98 \mathrm{~kg}$ \\
$\Delta \mathrm{FM}$ & $1.09 \mathrm{~kg}$ & $1.21 \mathrm{~kg}$ & $2.06 \mathrm{~kg}$ & $1.90 \mathrm{~kg}$ \\
\hline
\end{tabular}

The associated EMPs that lead to these changes were as follows:

\begin{tabular}{ccccc}
\hline & \multicolumn{2}{c}{ Lean } & \multicolumn{2}{c}{ Obese } \\
& High Carb. (HC) & High Fat (HF) & High Carb. (HC) & High Fat (HF) \\
\hline \multirow{2}{*}{ EPM } & $0.861 \mathrm{~kg}$ & $0.678 \mathrm{~kg}$ & $1.078 \mathrm{~kg}$ & $0.848 \mathrm{~kg}$ \\
\hline
\end{tabular}

Using the above data and standard numerical methods, we approximated that the remaining MBM parameters were:

\begin{tabular}{ccccc}
\hline & \multicolumn{2}{c}{ Lean } & \multicolumn{2}{c}{ Obese } \\
& High Carb. (HC) & High Fat (HF) & High Carb. (HC) & High Fat (HF) \\
\hline nEPM & $0.650 \mathrm{~kg}$ & $0.820 \mathrm{~kg}$ & $0.800 \mathrm{~kg}$ & $1.020 \mathrm{~kg}$
\end{tabular}


medRxiv preprint doi: https://doi.org/10.1101/2021.02.22.21252026; this version posted March 3, 2021. The copyright holder for this preprint (which was not certified by peer review) is the author/funder, who has granted medRxiv a license to display the preprint in perpetuity. It is made available under a CC-BY-NC-ND 4.0 International license.

Therefore, the MBM formulas for each diet are as follows:

Lean HC:

$$
\begin{gathered}
\mathrm{M}=\mathrm{EPM}+\mathrm{nEPM}=1.511 \mathrm{~kg} \\
\Delta \mathrm{BW}(\mathrm{t})=(1.511 / 0.019174-68.4)\left\{1-[1-0.019174]^{\mathrm{t}}\right\} \\
\Delta \mathrm{FM}(\mathrm{t})=19.29597 \mathrm{~W}\{(14.7 / 19.29597) \exp [\Delta \mathrm{BW}(\mathrm{t}) / 19.29597+14.7 / 19.29597]\}-14.7
\end{gathered}
$$

Lean HF:

$$
\begin{gathered}
M=E P M+n E P M=1.498 \mathrm{~kg} \\
\Delta B W(t)=(1.498 / 0.019173-68.4)\left\{1-[1-0.019173]^{t}\right\} \\
\Delta F M(t)=13.90792 W\{(14.7 / 13.90792) \exp [\Delta B W(t) / 13.90792+14.7 / 13.90792]\}-14.7
\end{gathered}
$$

Obese HC:

$$
\begin{gathered}
\mathrm{M}=\mathrm{EPM}+\mathrm{nEPM}=1.878 \mathrm{~kg} \\
\Delta \mathrm{BW}(\mathrm{t})=(1.878 / 0.01544-68.4)\left\{1-[1-0.01544]^{\mathrm{t}}\right\} \\
\Delta \mathrm{FM}(\mathrm{t})=26.04379 \mathrm{~W}\{(37 / 26.04379) \exp [\Delta \mathrm{BW}(\mathrm{t}) / 26.04379+37 / 26.04379]\}-37
\end{gathered}
$$

Obese HF:

$$
\begin{gathered}
M=E P M+n E P M=1.868 \mathrm{~kg} \\
\Delta B W(t)=(1.868 / 0.0157126-68.4)\left\{1-[1-0.0157126]^{t}\right\} \\
\Delta F M(t)=21.56814 \mathrm{~W}\{(37 / 21.56814) \exp [\Delta \mathrm{BW}(\mathrm{t}) / 21.56814+37 / 21.56814]\}-37
\end{gathered}
$$

All the above formulas are plotted in Figure 2. For further details, see the figure legend. 


\section{Lean $(68.4 \mathrm{~kg})$}

\section{A1}

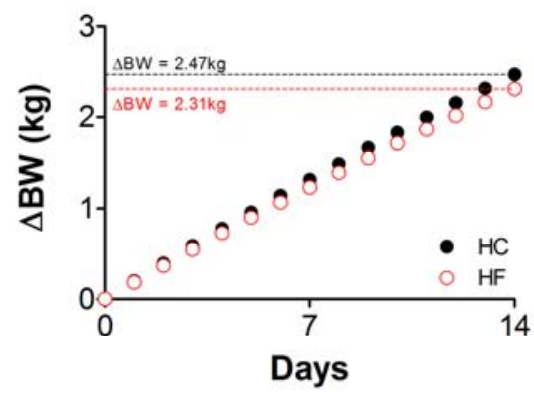

A2

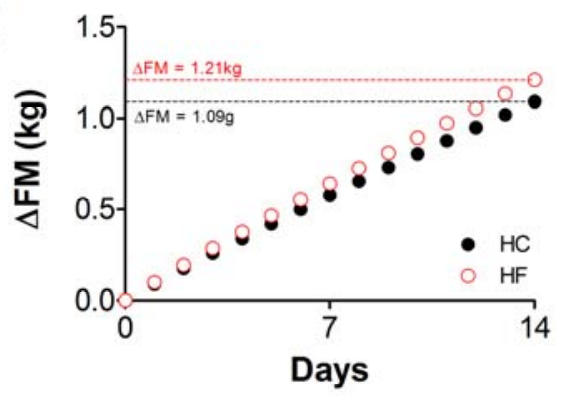

A3

A4
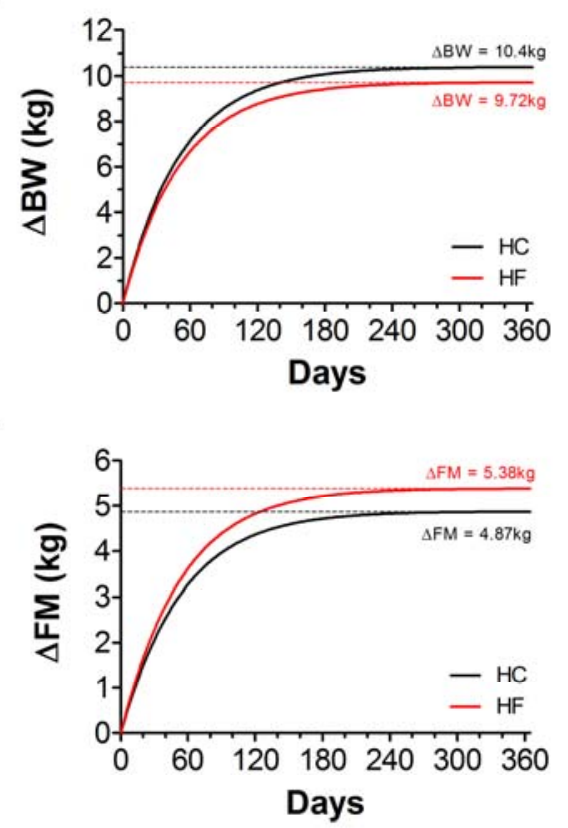

Obese $(103.9 \mathrm{~kg})$

B1

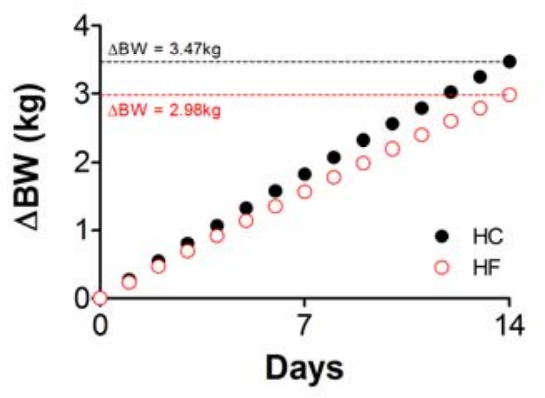

B2

B3
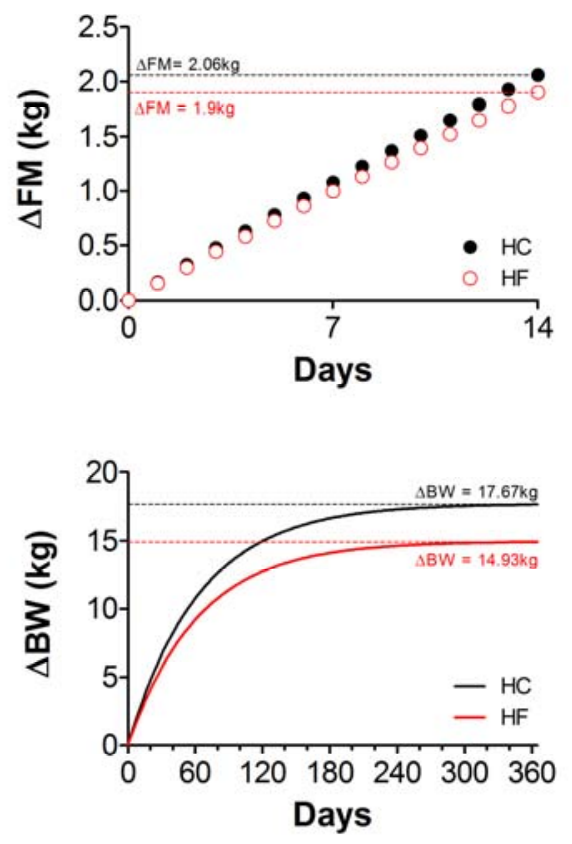

B4

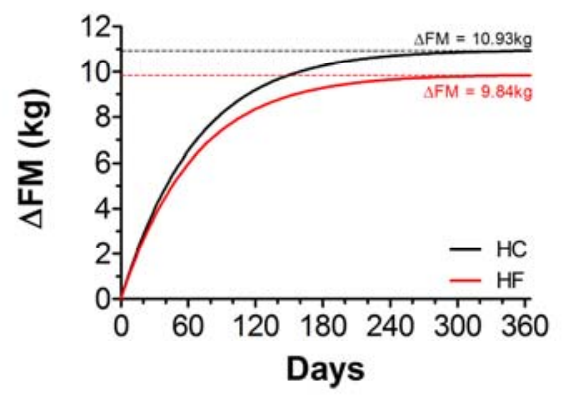

[FIGURE LEGEND STARTS] Figure 2. MBM simulation of Horton et al. overfeeding data. A1. MBM weight gain trajectories for the lean subjects perfectly match those reported by Horton et al. [4] over the trial duration (14 days). A2. Fat gain trajectories that underlay weight gain in A1 perfectly match those reported by Horton et al. [4] over the trial duration (14 days). Notice that the MBM predicts very similar levels of fat gain among diets over the 14 days. A3. The graph shows the same weight gain trajectories as 
medRxiv preprint doi: https://doi.org/10.1101/2021.02.22.21252026; this version posted March 3, 2021. The copyright holder for this preprint (which was not certified by peer review) is the author/funder, who has granted medRxiv a license to display the preprint in perpetuity.

It is made available under a CC-BY-NC-ND 4.0 International license .

in panel A1 but extended for 365 days. A4. The graph shows the same fat gain trajectories as in panel A2 but extended for 365 days. B1. MBM weight gain trajectories for the obese subjects perfectly match those reported by Horton et al. [2] over the trial duration (14 days). B2. Fat gain trajectories that underlay weight gain in B1 perfectly match those reported by Horton et al. [2] over the trail duration (14 days). Notice that the MBM predicts very similar levels of fat gain among diets over the 14 days. B3. The graph shows the same weight gain trajectories as in panel B1 but extended for 365 days. B4. The graph shows the same fat gain trajectories as in panel B2 but extended for 365 days. $\mathrm{HC}=$ high-carbohydrate diet; HF = high-fat diet. [FIGURE LEGEND ENDS]

\section{Discussion}

Recently, the validity of MBM was questioned [5] based on two feeding studies [3,4]. Thus, we decided to simulate both of these feeding trials $[3,4]$. Our "mass in, mass out" model (MBM) describes the temporal evolution of body weight and body composition under a wide variety of feeding experiments.

If 1) nEPM, 2) R, and 3) $\beta$ are the same between the diets, the diet with the greatest macronutrient mass will lead to greatest weight and fat gain during overfeeding, whereas the diet with the smallest macronutrient mass will result in greatest weight and fat loss during underfeeding. When these parameters (i.e., $n E P M, R, \beta$ ) are taking into consideration, MBM gives a remarkably accurate description of experimental data under a wide variety of feeding experiments (See also [1,2]).

\section{Conclusion}

Our results indicate that MBM is perfectly able to predict body weight and body composition fluctuations under a wide variety of feeding experiments. Thus, researchers around the world should acknowledge that the widely accepted EBT is clearly erroneous (See also [1,2]).

\section{Authors contribution}

Study concept and designing: Manninen, Arencibia-Albite

Acquisition of data: Manninen, Arencibia-Albite

Statistical analysis and interpretation of data: Manninen, Arencibia-Albite

Drafting the manuscript: Manninen, Arencibia-Albite

Critical revision of the manuscript for important intellectual content: Manninen, Arencibia-Albite

Administrative, technical or material support: Manninen, Arencibia-Albite.

Study supervision: N/A. 
medRxiv preprint doi: https://doi.org/10.1101/2021.02.22.21252026; this version posted March 3, 2021. The copyright holder for this preprint (which was not certified by peer review) is the author/funder, who has granted medRxiv a license to display the preprint in perpetuity.

It is made available under a CC-BY-NC-ND 4.0 International license .

\section{Funding sources}

This research did not receive any specific grant from funding agencies in the public, commercial, or notfor-profit sectors.

\section{Declaration of competing interests}

The authors declare that they have no competing interests.

\section{List of abbreviations}

$\mathrm{MBM}=$ mass balance model; $\mathrm{EBT}=$ energy balance theory; $\mathrm{BW}=$ body weight; $\mathrm{FM}=$ fat mass; $\mathrm{FFM}=$ fat free mass; $E P M=$ energy-providing mass; $n E P M=$ non-energy-providing mass; $R C=$ carbohydrate restricted diet; $\mathrm{RF}$ = fat restricted diet; $\mathrm{HC}=$ high-carbohydrate diet; $\mathrm{HF}=$ high-fat diet.

\section{References}

1. Arencibia-Albite F. Serious analytical inconsistencies challenge the validity of the energy balance theory. Heliyon. 2020 Jul 10;6(7):e04204. doi: 10.1016/j.heliyon.2020.e04204. Erratum in: Heliyon. 2020 Sep 14;6(9):e04609. PMID: 32685707; PMCID: PMC7355950.

2. Arencibia-Albite F, Manninen AH. Macronutrient mass intake explains deferential weight and fat loss in isocaloric diets.

medRxiv 2020.10.27.20220202; doi: https://doi.org/10.1101/2020.10.27.20220202

3. Hall KD, Bemis T, Brychta R, Chen KY, Courville A, Crayner EJ, Goodwin S, Guo J, Howard L, Knuth ND, Miller BV 3rd, Prado CM, Siervo M, Skarulis MC, Walter M, Walter PJ, Yannai L. Calorie for Calorie, Dietary Fat Restriction Results in More Body Fat Loss than Carbohydrate Restriction in People with Obesity. Cell Metab. 2015 Sep 1;22(3):427-36. doi: 10.1016/j.cmet.2015.07.021. Epub 2015 Aug 13. PMID: 26278052; PMCID: PMC4603544.

4. Horton TJ, Drougas H, Brachey A, Reed GW, Peters JC, Hill JO. Fat and carbohydrate overfeeding in humans: different effects on energy storage. Am J Clin Nutr. 1995 Jul;62(1):19-29. doi:

10.1093/ajcn/62.1.19. PMID: 7598063.

5. Klein S. "Mass Balance Model" is far from settled. Calories in Context. Feb 7, 2021. https://dylanklein.substack.com/p/mass-balance-model-is-far-fromsettled?token=eyJ1c2VyX2lkljoyNzEwMTI3NiwicG9zdF9pZCI6MzlyOTA5MzQsIl8iOiJjRONBdilsImlh 
medRxiv preprint doi: https://doi.org/10.1101/2021.02.22.21252026; this version posted March 3, 2021. The copyright holder for this preprint (which was not certified by peer review) is the author/funder, who has granted medRxiv a license to display the preprint in perpetuity. It is made available under a CC-BY-NC-ND 4.0 International license.

dCI6MTYxMzcyNjYzMywiZXhwljoxNjEzNzMwMjMzLCJpc3MiOiJwdWItMjY5MjQzliwic3ViljoicG9z dC1yZWFidGlvbiJ9.7Nd1SK1QDFHiQKyrnBut6Tt NWI 8U458PmlZUsT7pk (accessed 19/02/2021). 